\title{
Hunhu/ Ubuntu Philosophy incompatible with Business Ethics? Reflections on business viability in rural Shona communities in Zimbabwe
}

\author{
Elias G. Konyana \\ Department of Philosophy and Religious Studies, Great Zimbabwe University, ZIMBABWE
}

\begin{abstract}
Business has always been an important component of society from time immemorial. It is difficult to imagine a society that does not have a business sector where the exchange of goods and services takes place. However, business takes place within socio-cultural and ethical contexts. This article revisits Hunhu/ Ubuntu Philosophy (good ethical human behaviour) as observed by the Shona people of Zimbabwe and considers how it shapes business in rural Shona communities in Zimbabwe. It critically reflects on how rural businesspersons fare within the expectations of Hunhu/ Ubuntu viz-a-viz Western business approaches. Data were obtained from 100 informants randomly selected from rural Shona communities. The participants were former and current businesspersons involved in various lines of business. Among other issues, the interview questions were directed towards the people's motivation in starting business, the effects of Hunhu/ Ubuntu on business and the subsequent viability of rural businesses over the years. The responses provided helpful insights on the place of Hunhu/ Ubuntu in the African business environment.
\end{abstract}

Key words: Business, Hunhu/ Ubuntu, Shona community, sustainability

\section{Introduction}

Business is closely linked to, and is as old as, mankind and society. Nothing can be truer than saying that humankind and society, on one hand, cannot survive without business while business itself, on the other hand, needs people or society to flourish. Thus there is a symbiotic tripartite relationship between humankind, society and business. It is difficult to envisage a human society that does not have a business sector, that is, a segment where the exchange of goods and services takes place on a daily basis. However, it should be noted that all business activities take place within a socio-cultural and ethical environment which influences the business's operations. This articles investigates the place of Hunhu/ Ubuntu (good ethical human behaviour), as practised by the Shona people, in business in the rural communities of Zimbabwe. The paper begins by analysing the relationship between business and society in general drawing from the Western worldview before it turns to situate business activities in rural Shona communities within the dictates of Hunhu/ Ubuntu Philosophy. Finally, the article evokes the sustainability thesis in a bid to appraise the feasibility of establishing businesses in rural Shona communities in Zimbabwe. The findings of the paper are meant to situate Hunhu/ Ubuntu Philosophy within the global trends of undertaking sustainable business operations.

\section{Theoretical Framework}

The article adopts an Afro-centric approach. This is a theory that, according to Asante (2003), as cited in Hudson-Weems (2004, p.29) ${ }^{[1]}$ calls for the reviewing of all African phenomena, activities and ways of life in order to give them meaning from the standpoint and worldview of Africans. It argues that using Western perspectives to appreciate African realities hardly produces accurate and credible conclusions. Using the Afrocentric theory therefore allows for the exhibition of the rich values of the vast African traditions embedded in Africans' actions, behaviour and habits. The theory also makes a call for the consideration of African sociocultural and ethical values and ways of life such as Hunhu/ Ubuntu, in order to appreciate the diversity of humanity. From this theory, therefore, the article settles on Hunhu/ Ubuntu (good ethical human behaviour) and reflects on how it influences and affects business activities in rural Shona communities in Zimbabwe.

\section{Methodology}

This article makes use of the grassroots approach to studying a phenomenon. It utilises informal but indepth interviews and participatory observation practices to collect data for the study and incorporates the phenomenological approach as well in order to make authenticated generalisations of the findings. The grassroots approach is defined by Hudson-Weems (2004, p.36). ${ }^{[2]}$ as "the study of those living at the base of society, encompassing rural and urban areas in the developing and developed world" This is a bottom-up research process whose technique serves to gather ground-level perspectives from the targeted population. The 
strength of this approach lies in its emphasis on tapping into the indigenous knowledge base and expertise that substantiate the targeted community as the knowing subject. The approach also treats participants as agents of their own knowledge, not just objects to be examined, prodded or studied.

The phenomenological component of the grassroots method was employed in conducting informal interviews that were carried out among a total of one hundred former and current rural Shona businesspersons in Chimanimani, Chipinge and Buhera rural districts. The three rural districts were identified and chosen for their large numbers and sparse incidents of dysfunctional and struggling rural business operations. The strength of this method lies in its advocacy for the participants to speak for themselves. The informal interview technique allows for an honest face-to-face interaction with the participants in order to appreciate their emotions and share their fears and aspirations in view of their beliefs and cultural practices. However, the grassroots methodology is limited and biased to the study of the disadvantaged populations only. To cover up for this shortfall, the data so gathered was then fused with information obtained from secondary sources in order that the findings provided a wider range of application.

\section{Hunhu/ Ubuntu Philosophy in perspective}

The central question is: 'What is Hunhu/ Ubuntu Philosophy?' This section provides an attempt at a working definition of this philosophical concept. According to Nafukho (2006, pp. 409-411) ${ }^{[3]}$ Hunhu/Ubuntu is a multi-faceted African philosophical system that encompasses logic, metaphysics, epistemology and ethics. It is a philosophy that is concerned with the reinforcement of unity, oneness and solidarity among the Bantu people of Africa in general and southern Africa in particular. It is the characteristic flexibility and pragmatic nature of Hunhu/Ubuntu philosophy that makes it applicable in almost all facets of human life. As such, the concept has been wisely exported as an underlying philosophy or code of conduct into areas such as business, the legal system, education, religion, health, the environment, farming, mining, etc.

Traditionally and throughout Africa, the concept of Hunhu/Ubuntu, like most other traditions throughout the world, was passed on from one generation to the other mainly through oral tradition. This is pointed out by Ramose $\left(1999\right.$, p.78) ${ }^{[4]}$ who notes that African law founded on Hunhu/Ubuntu is a living law, based on its recognition of the continuous oneness and wholeness of the living, the living-dead and the unborn. It is generally believed that in pre-colonial African societies, the concept of Hunhu/Ubuntu was instrumental in sustaining social cohesion, managing peace and order for the good life of everyone in the society, including strangers and passersby.

Hunhu/ Ubuntu, as an indigenous African Philosophy, is itself well-documented in the works of many progressive African critical thinkers. It is adequately covered in works by Stanlake Samkange and Tommie Marie Samkange (1980) ${ }^{[5]}$, Carole Pearce (1990), ${ }^{[6]}$ Mongobe B. Ramose (1999) ${ }^{[7]}$, Ronald Nicolson (2008) ${ }^{[7]}$ and, recently, Fainos Mangena (2012) ${ }^{[9]}$ to mention only a few prominent ones. Hunhu or Unhu is a Shona term that refers to good ethical human behaviour or conduct. Shona is a local language spoken by the largest population of Zimbabwe. It is the mother tongue of about 80\% of Zimbabwe's population of close to 16 million people. It is the ensemble of six regional dialects, namely, Zezuru, Karanga, Manyika, Korekore, Ndau and Budya (Mashiri et al, 2002, p.221). ${ }^{10]}$ The term hunhu has its equivalent in IsiNdebele, ubuntu. IsiNdebele is another local language which is second to Shona in being spoken by a large population in Zimbabwe. According to Mangena (2012, pp.66-68) ${ }^{[11]}$, hunhu, like Western metaphysics, is anchored on Shona ontology and predication and these references imply more than being human. The Shona community therefore generally refers to a large area of Zimbabwe occupied by people of various Shona dialects such as the Zezuru in central Zimbabwe, the Korekore in the north, the Karanga in the south and the Manyika and Ndau located in the East of the country (Bourdillon, 1991, p.17). ${ }^{[12]}$ These people use the term hunhu to designate acceptable human conduct or behaviour (character). Thus they invariably say that munhu ane hunhu ndiye anodikanwa navamwe vanhu munharaunda (a person with good morals is always accepted by other people in the community). It is important to point out that rural Shona communities, like small, closely knit communities the world over, are constructed around kinship patterns. These traditional kinship systems have been responsible for governing much of the Shona people's cultural practices and morality. In entirely all activities, the Shona have been guided by hunhu on how they relate to each other, although there have been significant changes over the years due to the changing socio-economic and political landscapes. I argue that Shona culture is simultaneously individualistic and collective, although the latter overrides the former. Politeness and compassion, like morality, are also personal, as they are communal, for, 'in the final analysis the individual must take responsibility for his or her own actions' (Gombe, 1998, p.69). ${ }^{[13]}$

\section{Business and Ethics: The debate on compatibility}

Debate surrounding questions on the compatibility of ethics and business has been rife particularly in the Western world in recent years. The main contention is whether business activities should be evaluated ethically like most other human activities or not. However, there has been increasingly growing concern in 
recent years over the possibility and profitability of importing ethics into business activities. This concern has resulted in the development of divergent views concerning the compatibility of business and ethics. Two bipolar views have been more prominent, namely, the amoral business camp and the pro-business ethics camp, each camp advancing a set of principles that have garnered substantial following.

\subsection{The 'Myth of Amoral Business' explained}

The 'Myth of Amoral Business' is born out of the general belief that ethics is an ideal system which is all very noble in theory but not good for business. Albert Z. Carr (1968), as cited in R. Buchholz and S. B. Rosenthal, $\left(1998\right.$, p.14) ${ }^{[14]}$ claims that the business of business is to make profit, and not to moralise. Thus, the proponents of the myth argue that business is amoral, that is, business has nothing to do with morality. They further claim that in business moral considerations are not needed because morality does not bring profit. Thus, for them, business and ethics are incongruous since businesspersons can afford to practise all forms of bluffing in order to increase their profit margins. This scenario is acknowledged but vehemently contested by the University of Kansas ethicist, Richard T. De George (1986, pp. 69-70) ${ }^{[15]}$ who observes that business has been clouded with this kind of thinking. He also argues that, because people in business are concerned with profits, with producing goods and services and with buying and selling, they think that the economic system is free of values, which is misleading.

However, Thomas Beauchamp (1982, p.99) ${ }^{[16]}$ noted that the myth was created by the following misconceptions about the relationship between business and ethics. The following are some of the delusions such as:

- Ethics is inapplicable to the real world or to one's professional life.

- Ethics is a system of short and simple rules such as 'Do not lie', 'Do not kill' and 'Do not steal' which cannot be appropriate to the complexities of life.

- Morality is a system of puritanical prohibitions which cannot work in business.

- Indeed, good acts in business are to be commended not in moral terms but only in the cost/benefit language of "good business".

It is clear that the myth of amoral business has consequences that make ethical paralysis almost inevitable. It leads to the dog-eat-dog situation of the Darwinian Jungle of the 'survival of the fittest' which has since faced challenges in many societies today. The myth is slowly but surely being abandoned for the more enlightened corporate social responsibility approach which, as I argue in this article, has always been the acceptable approach.

\subsection{The Corporate Social Responsibility (CSR) perspective}

The Corporate Social Responsibility (CSR) is the antithesis of the amoral business approach. In this article I maintain that the Shona people's approach to business focused on the general good of the society. In general, the CSR is born from the belief that business activities, like all other human activities, are open to ethical evaluation. Proponents of ethics in the business environment argue that the myth of amoral business is misleading and cannot be relied on to sustain business itself. Richard T. de George $(1996, \mathrm{p} .13)^{[17]}$ claims that Corporate Social Responsibility, also called corporate conscience, corporate citizenship, social performance, or sustainable responsible business, is a form of corporate self-regulation integrated into a business model. CSR policy functions as a built-in, self-regulating mechanism whereby a business monitors and ensures its active compliance within the spirit of the law, ethical standards, and international norms. It is a process with the aim to embrace responsibility for the business' actions and encourage a positive impact through its activities on the environment, consumers, employees, communities, owners and all other members of the public who may also be considered as stakeholders. Proponents argue that corporations make more long term profits by operating with a perspective, while critics argue that CSR distracts from the economic role of businesses. That is why, in this paper I maintain that business in rural Zimbabwean communities has always been run on a CRS model informed by Hunhu/ Ubuntu Philosophy. The next section presents a synopsis of a typical rural Shona community.

\section{A synopsis of a rural Shona community}

The Shona people value kinship bonds, generosity, compassion and courtesy, all of which are key tenets enshrined in the Hunhu/ Ubuntu Philosophy. Among rural Shona, a number of extended families live together in a village community (Bourdillon, 1991, p.57). ${ }^{[18]}$ This arrangement makes the kinship bond strong and therefore every community member's behaviour or character is readily available for scrutiny. This strong kinship bond extends to unrelated neighbours because, according to Bourdillon (1991, p.62), ${ }^{[19]}$ Shona society is ideally egalitarian in the expectation that wealth should be evenly distributed throughout the community. He further observes that misfortune among the Shona, just like success, is a shared community responsibility. To this end, individual calamity is defined in contrast to the good fortune of another and the great success on the part of one person or family is believed to involve the disadvantage of others. This is so particularly because 
'mishonga' (good-luck medicines or charms) are frequently used to obtain good luck (Gelfand, 1956, p. 47). ${ }^{\text {[20] }}$ For this reason, individual richness or wealth brings unpopularity and suspicion on the individuals concerned. This can only be overcome by liberally using one's wealth for the benefit of one's kith and kin and the entire community. This is in keeping with the general belief among the traditional Shona society that good relations with the neighbourhood require generosity and liberal hospitality. It is this approach to business among the rural Shona that I argue that it is the same as the Corporate Social Responsibility approach to business. This is the case because, in the long run, the individual benefits from community acceptance and honour for their richness while the community also benefits from the generosity of the businessperson concerned. Gelfand (1973, p.80) ${ }^{[21]}$ argues that every member who contributed to the general harmony and welfare of the community was acceptable. Thus successful businesspersons can be acceptable in rural Shona communities only when they share their wealth with others.

\section{Pragmatic business function for rural business sustainability}

While the Shona people can be admired for their ability to apply principles of Corporate Social Responsibility in their own ways, there is need to appreciate the fact that there is a big gap now between the rural Shona and the urban Shona people. For the urban Shona, the desire to make excessive profit out of business has since taken over the goodwill motive of the communal Shona businessperson. In recent years and following the economic meltdown in Zimbabwe from the year 2000, many rural Shona businesspersons seemed to have abandoned Hunhu/ Ubuntu Philosophy in pursuit of personal enrichment characterised by unprecedented bluffing involving conscious misstatements, concealment and exaggeration. Thus, many rural businesspersons in various lines of business have not been accepted in their communities and some have had no option but to fold up operations. From the interviews that were carried out the informants acknowledged that they faced difficulties in balancing the individual and selfish pursuit of profit to sustain their businesses and the good reputation motive. In the end, those who settled for the profit motive found the going tough as their goods and services had dwindling consumer and customer bases. It then goes without saying that rural businesspersons heavily rely on their immediate communities and so they need to consistently be in keeping with the principles of Unhu/ Ubuntu for their businesses' sustainability.

\section{Conclusion}

The article has demonstrated that business is part and parcel of society, whether primitive, developing or developed. It has also argued that every society has a business approach that is regulated by the values of the concerned community's philosophy. The values that are used to evaluate all human actions are extendable to evaluating business conduct as well. In this paper, I have argued that the Shona are a people that value kinship relations and community harmony more than the individual's wellbeing. In the area of business, this paper has also argued that the Shona are motivated into doing business by various reasons, the chief reason being to serve the community. The Shona have also been portrayed as a people whose morality does not function on the level of social utility alone. These are people whose social interactions are heavily influenced by their kinship relations to the effect that any member of the Shona community who pursues individual success, particularly in business, is easily shunned and will not prosper. Thus, the Shona have always learnt to sustain their relations, even in business, through generosity, compassion and courtesy, which are the great tenets of Hunhu/Ubuntu Philosophy.

\section{References}

[1] C. Hudson-Weems, Africana Womanist Literary Theory (Asmara: Africa World Press, 2004).
[2] C. Hudson-Weems, Africana Womanist Literary Theory (Asmara: Africa World Press, 2004).

[3] F. M. Nafukho, Ubuntu Worldview: A Traditional African View of Adult Learning in the Workplace, Advances in Developing Human Resources, 8 (3), 408-415.

[4] M.B. Ramose, African Philosophy through Ubuntu. (Harare: Mond Books, 1999).

[5] S. Samkange and T. M. Samkange, Hunhuism or Ubuntuism: A Zimbabwean Indigenous Political Philosophy, (Salisbury: Graham Publishing Company).

[6] C. Pearce, Tsika, Hunhu and the Moral Education of Primary School Children, Zambezia XVII (ii), 1990, $145-160$.

[7] M.B. Ramose, African Philosophy through Ubuntu. (Harare: Mond Books, 1999).

[8] R. Nicolson, Persons in community: Ubuntu in the global village, in R. Nicolson (Ed.), Persons in Community: African Ethics in a Global Culture (Kwazulu-Natal: University of Kwazulu-Natal Press, 2008) 136-287.

[9] F. Mangena, On Ubuntu and Retributive Punishment in Korekore-Nyombwe Culture: Emerging Ethical Perspective (Harare: Best Practices Books, 2012).

[10] P. Mashiri, K. Mawondo and P. Tom, Naming the Pandemic: Semantic and Ethical Foundations of HIV/AIDS Shona Vocabulary, Zambezia XXIX (ii), 2002, 221-234.

[11] F. Mangena, On Ubuntu and Retributive Punishment in Korekore-Nyombwe Culture: Emerging Ethical Perspective (Harare: Best Practices Books, 2012).

[12] M. Bourdillon, The Shona Peoples: An Ethnography of the contemporary Shona, with special reference to their Religion (Gweru: Mambo Press).

[13] J. M. Gombe, Tsika Dze VaShona (Harare: College Press, 1998). 
[14] R. Buchholz and S. B. Rosenthal, Business Ethics: The Pragmatic Path Beyond Principles to Process (London: Prentice-Hall Inc., 1998)

[15] R. T. De George, Business Ethics, $2^{\text {nd }}$ Ed (New York: Macmillan, 1986).

[16] T. L. Beauchamp, Philosophical Ethics: An Introduction to Moral Philosophy (New York: McGraw-Hill, 1982).

[17] R. T. de George, Business Ethics (New York: Mac-Grow Hill, 1996).

[18] M. Bourdillon, The Shona Peoples: An Ethnography of the contemporary Shona, with special reference to their Religion (Gweru: Mambo Press).

[19] M. Bourdillon, The Shona Peoples: An Ethnography of the contemporary Shona, with special reference to their Religion (Gweru: Mambo Press, 1991).

[20] M. Gelfand, Medicine and Magic of the Shona (Cape Town: Juta, 1956).

[21] M. Gelfand, The Genuine Shona: Survival Values of an African Culture (Gweru: Mambo Press, 1973). 